\title{
What explains the negative effect of unemployment on health? An analysis accounting for reverse causality
}

\author{
Gerhard Krug \\ University of Erlangen-Nuremberg (FAU), gerhard.krug@fau.de; \\ Institute for Employment Research (IAB), Germany, gerhard.krug@iab.de \\ Andreas Eberl \\ Institute for Employment Research (IAB), Germany, andreas.eberl@iab.de
}

\begin{abstract}
The unemployed are often in poorer health than their employed counterparts. This cross-sectional correlation is often attributed to a causal effect of unemployment on health. Resent research analyzing longitudinal data, however, often supports alternative explanations, such as spurious correlation and/or selection of unhealthy workers into unemployment (i.e., reverse causality). In this paper, we apply a dynamic panel data estimator (system GMM) to account for both unobserved confounders and reverse causality. Despite some evidence for health selection, we still find strong support for the causality thesis. Furthermore, we show that the adverse health effect is partially explained by the loss of self-perceived social status due to unemployment but not by the loss of household income or social contacts.
\end{abstract}

This is a pre-print. The final version of the article was published as

Krug, Gerhard, and Andreas Eberl (2018). "What explains the negative effect of unemployment on health? An analysis accounting for reverse causality". Research in Social Stratification and Mobility 55: 25-39. https://doi.org/10.1016/j.rssm.2018.03.001

\section{Acknowledgement}

For fruitful discussions and helpful comments we thank our colleagues at the Research Department E2 "Joblessness and Social Inclusion", participants of the RC 28 spring conference 2017 in Cologne, of the workshop "Analytical Sociology" in Venice 2017 and especially Josef Brüderl and Tobias Wolbring. Any remaining errors are our own. 


\section{Introduction}

It is well documented that the unemployed are in worse health compared to their employed counterparts (Kroll, Müters, and Lampert 2016). However, there are three distinct but not mutually exclusive explanations for this difference: social causation, indirect selection and direct (or health) selection. The first and long-standing social causation explanation assumes that becoming unemployed is damaging to an individual's health (for overviews see Brand 2015; Wanberg 2012). Unemployment is considered a stressful life event (cf., Pearlin 1989) that creates distress and leads to health problems. In support of this explanation, a variety of mechanisms - again, none of them mutually exclusive - have been put forward. One of the most comprehensive discussions of this issue is provided by Jahoda (1981), who distinguished between the manifest and latent functions of work. In this framework, becoming unemployed leads to a loss of these functions and consequently to a deterioration of health. First and foremost, the unemployed are deprived of the manifest function of work, i.e., to provide the necessary financial means so that they can support themselves and their families. In addition, however, work fulfills a variety of latent functions. Work not only enables individuals to contribute to a collective purpose and structures their daily activities, it also provides status and societal recognition and widens individuals' social networks beyond family. Despite a long research tradition, the literature is often criticized for not testing the pathways or mechanisms underlying the social causation thesis (Bartley 1994; Janlert and Hammarström 2009). This is unfortunate because, as argued by Goldthorpe (2001), for example, a test of the hypothetical mechanism underlying a causal relationship can improve the ability of statistical analysis to provide us with convincing evidence of the existence or absence of this causal relationship.

Testing the underlying mechanisms of social causation is even more important, given that social causation is, by far, not the only explanation for the unemployment-health relationship. A second explanation refers to "indirect selection", i.e., the assumption that the relationship between health and unemployment might be mainly due to common causes. For example, workers with lower education have a higher risk of becoming unemployed (Mincer 1991; Wolbers 2000). At the same time, education is positively related to health (Grossman 1972; Conti, Heckman, and Urzua 2010). As a consequence, the common cause creates compositional differences such that the unemployed tend to be in poorer health than their employed counterparts. Accounting for indirect selection in quantitative research is a matter of controlling for all common causes, including those unobserved in the data, by suitable statistical methods.

Third, other scholars argue that there is a direct selection of unhealthy workers into unemployment. Sometimes, the term "reverse causality" is used to indicate that, compared to the social causation thesis, the direct selection explanation reverses the causal order between unemployment and health. The theoretical argument behind direct selection is that those workers whose health deteriorates become less productive and are more likely to be laid off (West 1991; Bartley 1988; Cook 1985). Several authors have 
found at least some empirical evidence for direct selection (Andreeva et al. 2015; Heggebø 2015; Strully 2009; Virtanen et al. 2006; Stewart 2001; McDonough and Amick 2001; Korpi 2001). Of course, the social causation and direct selection explanations are not mutually exclusive. However, most research designs do not effectively distinguish empirically between the two. As a consequence, empirical results in support of social causation are often criticized by referring to the possibility of direct selection as an alternative explanation.

In the analysis below, we attempt to go beyond the current literature by making the following contributions. First, we aim to identify the net effect of social causation by explicitly ruling out both indirect and direct selection as alternative explanations. We do this by applying a dynamic panel data regression based on the generalized method of moments (GMM). Distinguishing between social causation and selection is important because the two explanations have very different implications for policymakers. In cases of social causation, it would make sense to take measures to avoid (prolonged) unemployment. In case of (direct) health selection, such measures will only induce costs but will be ineffective. Here, measures to foster the health of employed individuals would be more efficient. Second, we aim to further investigate the social causation effect by testing several causal mechanisms, namely those based on the reduction in financial resources, social network resources and self-perceived social status. Identifying the relevant mechanisms will help policy makers to better focus potential measures against the adverse health effects of unemployment.

The article proceeds as follows: In the next section, we review the literature on social causation and derive our hypotheses. We then describe our data - the German Panel Study "Labour Market and Social Security" (PASS) - and the dynamic panel data estimator based on the generalized method of moments as our method of choice. After presenting our results, we conclude with a discussion.

\section{Unemployment and health: Literature review and hypotheses}

With regard to indicators of physical and psychological health, the unemployed are in poorer health compared to employed individuals. The largest part of the literature on health and unemployment is based on cross-sectional data analysis (cf., Paul and Moser 2009). Cross-sectional data allow researchers to control for the observed part of those variables that induce indirect selection. In the last two decades or so, researchers have become more sensitive to the problem of unobserved confounders when making causal claims and to the advantages of longitudinal data. When using longitudinal data, the bias due to indirect selection based on unobserved variables can be eliminated by applying fixed-effects regressions or similar methods, such as difference-in-differences estimation, as long as the influence of these unobserved 
confounders is constant over the observation period of the study (Andreß, Golsch, and Schmidt 2013; Brüderl and Ludwig 2015).

The results of studies that apply such stricter methods of causal estimation are more heterogeneous, however, than the results of studies based on cross-sectional data ${ }^{1}$. Some authors who use longitudinal data also report negative and statistically significant causal effects on health or health-related behavior, e.g., Young (2012) for the US; Minelli et al. (2014) for Italy; Marcus (2014) for Germany; Mandemakers and Monden (2013) for the UK; and Cygan-Rehm, Kuehnle, and Oberfichtner (2017) for the US, UK, Australia and Germany. Tøge and Blekesaune (2015) find negative causal effects for Europe and identify no negative health trends preceding unemployment that might point towards direct selection. Other authors report results that are more ambiguous or even point to no causal effects of unemployment. For Germany, Gebel and Voßemer (2014) find statistically negative effects on life satisfaction but no effects on health satisfaction. For Finland, Böckerman and Ilmakunnas (2009) find no effects of unemployment on health, but they do find that those who eventually become unemployed are in worse health than those who do not. They interpret this as support for the direct selection thesis. For Sweden, Korpi (2001) finds no effects for current unemployment, but the effects of past unemployment duration are statistically significant. In addition, the author also finds that ill health increases the risk of becoming unemployed. Therefore, he finds support for both the direct selection and social causation theses. Salm (2009) investigates firm closures in the USA and also finds no effect, concluding that the correlation of health and unemployment is due to indirect selection. Black, Devereux and Salvanes (2015) use Norwegian data indicating that the effects of unemployment on coronary disease are significant but very small. For Germany, Schmitz (2011) finds negative health effects of unemployment, but not for the unemployed who lose their jobs due to firm closure. Schmitz (2011) interprets this finding as evidence for direct selection. If unemployment is due to firm closure, selection based on poor health is unlikely because all employees lose their jobs. If this group of unemployed shows no health effects, but other unemployed do show such effects, this points to pure selection effects ${ }^{2}$. Heggeb $\varnothing$ (2015) explicitly and exclusively focuses on direct selection and finds significantly effects of poor health on unemployment in Denmark, no effect in Norway, and significantly negative effects of unemployment in Sweden.

\footnotetext{
${ }^{1}$ The literature also uses so-called prospective studies, which are based on two-wave longitudinal data. These studies compare individuals who did and did not become unemployed between two points in time. Control variables are measured at time 1, including baseline health. Health outcome, in contrast, is measured at time 2 . Such studies are slightly better equipped to control for indirect selection, but unobserved heterogeneity is only partly accounted for. Paul and Moser (2009) report that in general, such studies report smaller correlations than cross-sectional studies, but differences between the unemployed and employed are still statistically significant.

${ }^{2}$ However, see Morris and Cook (1991) for a comprehensive critique of using firm closures to research unemployment effects on health.
} 
In all, research that eliminates the bias that is due to unobserved confounders only partly supports the social causation thesis. In contrast, several studies point to the relevance of indirect selection as an alternative explanation for the unemployment-health relationship. However, given that longitudinal data analyses, e.g., those based on fixed-effects regressions, do not - per se - distinguish between social causation and direct selection (i.e., reverse causality, see the method section below), the empirical validity of the social causation effect is still largely open to debate. Therefore, our first hypothesis is the following:

\section{H1: There is a negative causal effect of unemployment on health}

Research on the effects of unemployment on health rarely also tests for one or more of the underlying mechanisms. Those who perform such tests mostly apply methods that do not account for indirect selection based on unobserved confounders (Paul, Geithner, and Moser 2009; Kessler, Turner, and House 1987; Kokko and Pulkkinen 1998). One of the most common explanations for the social causation effect of unemployment on health is the loss of financial resources. As the manifest function of work is to provide workers with income, the loss of work means the loss of this income. This might lead to a lack of financial resources to buy health-promoting goods, live in a healthy environment, exercise, etc. Lower financial resources might also be damaging to health because of the stress and shame associated with having to cope with reduced financial resources (Peacock, Bissell, and Owen 2014). However, the literature finds only small or statistically insignificant effects of household income on health (Frijters, Haisken-DeNew, and Shields 2005; Meer, Miller, and Rosen 2003; Contoyannis, Jones, and Rice 2004). Unfortunately, whether income is or is not controlled for varies among the studies cited above. Only Young (2012) explicitly tests the income mechanism while accounting for indirect selection. He finds no mediating effects of changing household income or eligibility for unemployment benefits. Additionally, Foverskov and Holm (2016) find no effects of household income on health in a regression that accounts for reverse causality. However, we are not aware of any research on income as a mechanism explaining health outcomes of unemployment that also accounts for potential direct selection effects.

H2.a: The negative causal effect of unemployment is (in part) explained by the reduced financial resources of the unemployed

As is emphasized by Jahoda (1981), job loss is associated with the loss of not only the manifest but also the latent functions of work. One of these functions is the loss of social status. Much research has been conducted regarding the effect of objective socioeconomic status on health, mostly measured as income, education and/or occupation (Oakes and Rossi 2003). The concept is less applicable, however, if the 
employed and unemployed are to be compared ${ }^{3}$. More recently, researchers noted the importance of subjective social status, which "refers to the individual's perception of his own position in the status hierarchy" (Jackman \& Jackman 1973), for various health outcomes (Cohen et al. 2008; Wolff et al. 2010; Demakakos et al. 2008; Netuveli and Bartley 2012). If unemployment impacts the unemployed person's perception of his/her social status, this might explain the negative health-unemployment relationship. Whereas Gundert and Hohendanner (2014) find that unemployment has a significantly negative causal effect on the rather similar concept of "self-perceived social exclusion," we are not aware of any research that tests self-perceived status as a mechanism for the health-unemployment relationship while also accounting for direct health selection.

H2b: The negative causal effect of unemployment is (in part) explained by the reduced subjective social status of the unemployed

The third mechanism is concerned with Jahoda`s (1981) latent function, according to which employment provides access to a wider social network. There is a substantial body of research that suggests that networks play an important role in providing access to social support and social resources, and they thereby exert social influence that impacts an individual's health and health behavior (Berkman et al. 2000; Thoits 2011). If structures and characteristics of the respective networks determine the amounts of support, resources and influence available to the individual, a change in the social network can lead to a deterioration of health. Several researchers have documented that unemployment might lead to substantial changes in the social network (Jones 1988; Lindsay 2009). For example, for many individuals, it is work that embeds them in specific networks. Another explanation posits that the unemployed withdraw actively from parts of their networks due to shame or due to the lack of means to engage in reciprocal exchange. However, the role of social networks as mediators of the causal pathways between unemployment and health is rarely tested explicitly, and no research that accounts for direct selection has come to our attention.

H2c: The negative causal effect of unemployment is (in part) explained by the changed social network of the unemployed

\footnotetext{
${ }^{3}$ The key components of socioeconomic status are occupational prestige, education and income. The last is already contained in the manifest function of work, whereas the level of education is, in general, not influenced by unemployment. Finally, occupational prestige is an applicable concept for employed individuals only and is not applicable for the unemployed.
} 


\section{Data and method}

In our analysis, we use the German Panel Study "Labour Market and Social Security" (PASS) (Bethmann et al. 2013; Trappmann et al. 2013). PASS is a household survey that uses a dual frame for sampling: the first subsample is a probability sample of the German residential population and includes the short-term unemployed. The second subsample is drawn from registers of welfare benefit recipients, including the long-term unemployed. At the time of writing, eight waves were available for research. The questionnaire ${ }^{4}$ focuses on labor market-related issues and on transfer payments as well as on the material and social conditions of households and social inclusion. In PASS, information on unemployment and employment is collected in spell format, and details are provided at the monthly level. In wave 1, respondents were asked about their current employment status. From wave 2 onward, this information was updated using dependent interviewing. Information is collected on the timing and conditions of employment and unemployment, making it an ideal sample with which to study the unemployed in comparison to regular employed labor market participants.

We restrict our sample to individuals in the working age range of 16 to 64 . Students and retirees, as well as individuals who are unable to work due to severe health problems or disabilities, are excluded. The main dependent variable is satisfaction with health ("How satisfied are you with your health?"), measured on a scale from 0 to 10 . However, for the purpose of sensitivity checks, we also used self-rated health ("How would you describe your state of health in the past 4 weeks in general?") and psychological health ("How strongly have you been affected by mental problems, such as fear, dejection or irritability in the past 4 weeks?“) as alternative outcomes, both measured on a five-point scale. The key independent variable is unemployment. Individuals are classified as unemployed if they are registered with the local employment office. Individuals are classified as employed if they are in gainful employment that is subject to social security contributions (i.e., no marginal employment). Individuals are classified in a residual category if they gave their current status as homemaker or as on parental leave. To account for the financial resources of the unemployed, we used gross household income. The measure includes wages in the case of employment and unemployment benefits in the case of unemployment. To measure social networks, we acknowledge the fact that the social network literature often distinguishes between strong and weak ties (Granovetter 1973), a distinction also of relevance in the field of health research (Ferlander 2007; Thoits 2011). Therefore, we use two measures: the number of close friends or relatives outside of the household and a dummy variable for active membership in voluntary associations. Where the former reflects the strong-tie part of the network, the latter is often used as an indicator of weak ties (cf., Ruiter and De Graaf 2009). Self-perceived social status is measured on a scale ranging from 1 to 10 . To indicate

\begin{tabular}{l}
\hline $4 \quad$ All questionnaires and PASS documentation \\
http://fdz.iab.de/de/FDZ Individual_Data/PASS/Working Tools.aspx.
\end{tabular}


that lower social status is damaging health, we recoded the item (1: highest social status; 10 lowest social status $)^{5}$. A number of control variables are included to account for compositional differences between employed and unemployed individuals, including age, gender, years of schooling, marital status, migration background, current employment duration, and previous unemployment duration, as well as dummies for survey waves and a dummy for the respective subsample. For descriptives of the dependent and independent variables see the appendix, Table A1.

Because they are aware of the problem that indirect selection need not be based exclusively on the variables observed in the data, researchers (see literature review above) now often rely on panel data and apply fixed effects regression estimators (Halaby 2004; Brüderl and Ludwig 2015; Allison 2009) to account for observed and unobserved composition indirect selection effects. The application of fixedeffects or similar estimates is state of the art, but it is not without limitations. First, fixed-effects do control for unobserved confounders, but they do so at the cost of statistical power. Only those who change their status from employed to unemployed or vice versa contribute to the estimate (Brïderl and Ludwig 2015). Therefore, some of the null effects in the literature might be explained by low statistical power instead of the absence of adverse health effects. Second, fixed-effects regressions cannot control for the direction of causality (Gunasekara et al. 2014) ${ }^{6}$. A statistically significant coefficient in a fixed-effects regression indicates that a within-person change between waves in the focal independent variable is associated with a within-person change in the dependent variable. This within estimate presents a stronger argument for causality than do mere static comparisons between persons with different levels of the focal dependent and independent variables (between variation). In many research settings, researchers unfortunately have no information about which change came first - the change in unemployment or the change in health. In such cases, the fixed-effects estimate is agnostic with regard to the direction of the causal influence between variables. This methodological restriction, however, is only rarely acknowledged in applied research, and the literature on the health effects of unemployment is no exception.

In our analysis below, we first estimate a pooled regression, which accounts for observed indirect selection. Second, we apply fixed-effects regression to account for any additional unobserved indirect selection effects. To investigate the timing of health deterioration, we then augment the fixed effects estimate by using a dummy impact function approach (Andreß, Golsch, and Schmidt 2013). Realizing that the results are still ambiguous with regard to the matter of social causation and direct selection, we apply the "system generalized method of moments (system GMM)" estimator, a panel regression

\footnotetext{
${ }^{5}$ The original Question was: "There are groups in our society, which are considered to be rather at the top while other groups seem to be positioned at the bottom. Where would you see yourself using the numbers 1 to 10 ? 1 means that you see yourself at the very bottom, 10 means, that you are positioned at the very top. The numbers from 2 to 9 allow you to grade your assessment."

${ }^{6}$ We do not, however, claim that all situations where fixed-effects estimators are applied are plagued by the problem of reverse causality, but in the case of unemployment and health, we are claiming that this is a problem.
} 
estimator that specifically aims to avoid bias due to reverse causality ${ }^{7}$. This system GMM estimator was developed by Arellano and Bover (1995) and is an extension of the dynamic panel data regression proposed by Arellano and Bond (1991; see also Blundell and Bond 1998) that alleviates some of the latter's weaknesses.

System GMM estimates two equations simultaneously, both of which estimate the same coefficients (cf., Averett, Argys, and Kohn 2014). For the first equation, all variables are transformed into first differences, i.e., the differences between two consecutive waves, whereas the second equation uses the same variables untransformed, i.e., their levels. Computationally, the differences are simply added as additional observations to the data set. Whereas the first equation removes time-constant unobserved heterogeneity, both equations control for all other types of heterogeneity and eliminate reverse causality problems by instrumentation. In both equations, the lagged dependent variable, as well as variables assumed to be endogenous, are instrumented by so-called internal instruments. Such instruments are internal in the sense that they are constructed from past values of the same variables. In equation 1, lagged variables in levels instrument the differences; in equation 2, lagged differences instrument the levels (Roodman 2009a). We treat the following variables as endogenous: unemployment, status "out of labor force", current unemployment duration, previous unemployment experience, current employment duration, household income, social network indicators, and self-perceived social status. By treating many of our control variables as well as the mechanism variables as subject to reverse causality, we go well beyond most applications that only treat their focal independent variable as endogenous. Because too many lags lead to weak instruments, we used a lag structure of, at maximum, 2 lags to construct the instruments. However, our results are not sensitive with regard to the choice of the number of lags (see appendix, Table A7). We treat age, gender, education, migration background, marital status and the number of children in the household as exogenous.

Several assumptions of the system GMM can be tested, and we will report the respective results below and discuss them in more detail in the appendix. Tests and estimation are conducted with the Stata add-on xtabond2 (Roodman 2009b; see also Baum and Schaffer 2003; Piper 2015). Compared to fixed-effects estimates, system GMM not only accounts for reverse causality but also controls for time-varying unobserved confounders. Unlike to the fixed-effects estimate, the causal effect is not exclusively based on individuals who change their employment status (within variance), thus focusing on a potentially selective sub-group by excluding individuals, who are continuously employed or unemployed during the observation period. Furthermore, system GMM gives estimates for variables that are constant over the

\footnotetext{
${ }^{7}$ We turn to this estimator, because intuitive solutions that remain within the fixed-effects framework like timelagging the independent (Vaisey and Miles 2017) or the dependent variable (Nickell 1981) can do more harm than good.
} 
observation period, such as gender. The system GMM estimator is well suited for unbalanced panels and gaps in the panel structure.

\section{Results}

In this section, we will present results from our empirical analysis. We start with Model 1 in Table $1^{8}$, where the pooled panel data regression only controls for the part of indirect selection that is captured by the control variables. We find that current unemployment is significantly associated with a -0.827 point loss in health on the 11-point scale, net of previous unemployment experience and other confounding influences. Notably, the negative coefficient is reduced to -0.248 but remains statistically significant, once the fixed-effects estimator in Model 2 controls for unobserved indirect selection, too. Model 3 replaces the binary indicator with unemployment duration, finding that with every additional month of unemployment, health is lower by -0.003 points. Following the methodological discussion above, these estimates provide evidence for a causal relationship between unemployment and health, but not in the direction of this causality. We can, however, analyze the time trajectory of health before and after unemployment by way of a dummy impact function.

Model 4 presents results from such a dummy impact function, where the first year of unemployment is the reference category. During the two or more years before entering unemployment, health is, on average, 0.211 points higher than during the first year of unemployment. This difference is statistically significant. However, compared to two or more years before, in the year immediately prior to unemployment, health is deteriorating. The coefficient is now only 0.0588 and is statistically not different from health status during unemployment. In line with the result from Model 3, we see that health deteriorates further with continued unemployment. The fact that health is already deteriorating before individuals enter unemployment, however, is consistent with direct selection, wherein health shocks lead to unemployment. However, a similar pattern will also arise when individuals` health declines as a reaction react to the stress of anticipating unemployment (e.g., Ferrie et al. 1995). To isolate the social causation effect of unemployment, Models 5 and 6 apply the GMM panel data estimator. Here, the coefficient reflects only the unidirectional effect of unemployment on health. As we can see, both for unemployment incidence and unemployment duration, the coefficients are negative and statistically significant. However, we cannot directly compare the system GMM coefficients with the fixed-effects estimates because the former are only the concurrent effect of unemployment on health, whereas the effects of past values are captured by

\footnotetext{
${ }^{8}$ The results reported in Table 1 are, in part, based on different sample sizes. This is due to specific restrictions that each method imposes on the data. Notably, the GMM uses the first two waves to construct the instruments and to control for the lagged health, but not directly for the health regression.
} 
the lagged dependent variable. Therefore, the empirical evidence strongly supports the social causation thesis (Hypothesis 1), despite evidence for potentially additional direct selection effects.

Table 1: Effect of unemployment on health at $t_{0}$

\begin{tabular}{|c|c|c|c|c|c|c|}
\hline & Model (1) & Model (2) & Model (3) & Model (4) & Model (5) & Model (6) \\
\hline & Pooled OLS & FE & FE & FE & sysGMM & sysGMM \\
\hline & $\begin{array}{l}\text { Coeff } \\
\text { (std.err) }\end{array}$ & $\begin{array}{c}\text { Coeff } \\
\text { (std.err) }\end{array}$ & $\begin{array}{l}\text { Coeff } \\
\text { (std.err) }\end{array}$ & $\begin{array}{l}\text { Coeff } \\
\text { (std.err) }\end{array}$ & $\begin{array}{c}\text { Coeff } \\
\text { (std.err) }\end{array}$ & $\begin{array}{l}\text { Coeff } \\
\text { (std.err) }\end{array}$ \\
\hline Unemployed at $\mathrm{t}_{0}$ & $\begin{array}{c}-0.827 * * * \\
(0.0331)\end{array}$ & $\begin{array}{r}-0.248 * * * \\
(0.0314)\end{array}$ & & & $\begin{array}{c}-0.573 * * * \\
(0.104)\end{array}$ & \\
\hline $\begin{array}{l}\text { Unemployment duration (in } \\
\text { month) at } t_{0}\end{array}$ & & & $\begin{array}{c}-0.003^{* * *} \\
(0.0006)\end{array}$ & & & $\begin{array}{c}-0.007 * * * \\
(0.0012)\end{array}$ \\
\hline $\begin{array}{l}>=2 \text { years prior to } \\
\text { unemployment (employed) }\end{array}$ & & & & $0.211 * * *$ & & \\
\hline $\begin{array}{l}1 \text { year prior to } \\
\text { unemployment (employed) }\end{array}$ & & & & $\begin{array}{c}(0.0605) \\
0.0588 \\
(0.0469)\end{array}$ & & \\
\hline $\begin{array}{l}\text { Reference } 1^{\text {st }} \text { year of } \\
\text { unemployment) }\end{array}$ & & & & & & \\
\hline 2nd year of unemployment & & & & $\begin{array}{l}-0.181^{*} \\
(0.0723)\end{array}$ & & \\
\hline$>2$ nd year of unemployment & & & & $\begin{array}{l}-0.220^{*} \\
(0.0955)\end{array}$ & & \\
\hline Covariates & $\checkmark$ & $\checkmark$ & $\checkmark$ & $\checkmark$ & $\checkmark$ & $\checkmark$ \\
\hline Observations & 69,734 & 69,734 & 68,608 & 69,734 & 31,969 & 31,647 \\
\hline Number of persons & 21,063 & 21,063 & 20,852 & 21,063 & 11,512 & 11,403 \\
\hline
\end{tabular}

*** $\mathrm{p}<0.001, * * \mathrm{p}<0.01, * \mathrm{p}<0.05, \# \mathrm{p}<0.10$; robust standard errors

OLS: Pooled ordinary least squares regression; FE: Fixed Effects Regression; sys GMM: System generalized method of moments;

Controls are: years of schooling, marital status, dummy for out of labor force; previous time in unemployment, current employment duration, gender, migration background, subsample dummy, dummies for survey wave/year; FE excludes time-constant covariates and age

Full regression tables can be found in the appendix, Table A2

Turning to the mechanisms that are proposed in the literature to explain the social causation effect, we start with income. Unemployment is often associated with a considerable reduction in income. For a better comparison, Model 1 in Table 2 repeats the GMM results from Table 1. If the loss of income is the reason for the adverse health effects of unemployment, the regression coefficient should become smaller or even insignificant once income is accounted for. Model 2 introduced household income as a further covariate. As we can see, not only is there no effect of household income on health per $\mathrm{se}^{9}$, including income leaves

\footnotetext{
${ }^{9}$ This is also the case after accounting for a nonlinear effect of income by introducing a squared income term.
} 
the coefficient virtually unchanged. Income loss due to unemployment does not explain the negative health effects, and we conclude the data does not support hypothesis $2 \mathrm{a}$.

The second mechanism concerns the mediating effect of self-perceived social status (Table 2, Model 3). In contrast to income, self-perceived social status has a significantly negative effect on health, where a one point reduction on the 10-point scale of self-perceived social status amounts to a heath reduction of -0.260 points. Furthermore, after including this measure in the analysis, the negative effect of unemployment decreases to -0.315 but remains statistically significant. Thus, we find that the data supports hypothesis $2 \mathrm{~b}$; that is, self-perceived social status explains part of the negative causal effect of unemployment on health.

\section{Table 2: Effect of unemployment on health at $t_{0}$}

\begin{tabular}{|c|c|c|c|c|c|c|}
\hline & Model (1) & Model (2) & Model (3) & Model (4) & Model (5) & Model (6) \\
\hline & sysGMM & sysGMM & sysGMM & sysGMM & sysGMM & sysGMM \\
\hline & $\begin{array}{l}\text { Coeff } \\
\text { (std.err) }\end{array}$ & $\begin{array}{c}\text { Coeff } \\
\text { (std.err) }\end{array}$ & $\begin{array}{l}\text { Coeff } \\
\text { (std.err) }\end{array}$ & $\begin{array}{l}\text { Coeff } \\
\text { (std.err) }\end{array}$ & $\begin{array}{l}\text { Coeff } \\
\text { (std.err) }\end{array}$ & $\begin{array}{c}\text { Coeff } \\
\text { (std.err) }\end{array}$ \\
\hline Unemployed at $\mathrm{t}_{0}$ & $\begin{array}{c}-0.573 * * * \\
(0.104)\end{array}$ & $\begin{array}{c}-0.582 * * * \\
(0.106)\end{array}$ & $\begin{array}{l}-0.315^{*} \\
(0.131)\end{array}$ & $\begin{array}{c}-0.558^{* * *} \\
(0.104)\end{array}$ & $\begin{array}{c}-0.600^{* * *} \\
(0.105)\end{array}$ & $\begin{array}{c}-0.337 * * \\
(0.126)\end{array}$ \\
\hline $\begin{array}{l}\text { Household income (in } 100 \\
€) \text { at } t_{0} \\
\text { Self-perceived Social } \\
\text { Status at } t_{0}(\text { low }=10)\end{array}$ & & $\begin{array}{l}-0.00206 \\
(0.00398)\end{array}$ & $-0.260 * * *$ & & & $\begin{array}{l}-0.00670 \\
(0.00445) \\
-0.280 * * *\end{array}$ \\
\hline Strong Ties at $t_{0}$ & & & $(0.0752)$ & $\begin{array}{l}0.00443 \\
(0.0174)\end{array}$ & & $\begin{array}{l}(0.0709) \\
0.00330 \\
(0.0149)\end{array}$ \\
\hline Weak Ties at $t_{0}$ & & & & & $\begin{array}{l}-0.192 \\
(0.172)\end{array}$ & $\begin{array}{l}-0.243 \\
(0.168)\end{array}$ \\
\hline Covariates & $\checkmark$ & $\checkmark$ & $\checkmark$ & $\checkmark$ & $\checkmark$ & $\checkmark$ \\
\hline Health at $\mathrm{t}_{-1}$ & $\begin{array}{c}0.195 * * * \\
(0.0165)\end{array}$ & $\begin{array}{c}0.195 * * * \\
(0.0164)\end{array}$ & $\begin{array}{l}0.188^{* * *} \\
(0.0169)\end{array}$ & $\begin{array}{c}0.196^{* * *} \\
(0.0165)\end{array}$ & $\begin{array}{c}0.198 * * * \\
(0.0166)\end{array}$ & $\begin{array}{l}0.192^{* * *} \\
(0.0168)\end{array}$ \\
\hline Health at $\mathrm{t}_{-2}$ & $\begin{array}{c}0.0779 * * * \\
(0.0131) \\
\end{array}$ & $\begin{array}{c}0.0781 * * * \\
(0.0131) \\
\end{array}$ & $\begin{array}{c}0.0723 * * * \\
(0.0134) \\
\end{array}$ & $\begin{array}{c}0.0777 * * * \\
(0.0132) \\
\end{array}$ & $\begin{array}{c}0.0790 * * * \\
(0.0133) \\
\end{array}$ & $\begin{array}{c}0.0766 * * * \\
(0.0134) \\
\end{array}$ \\
\hline Constant & $\begin{array}{c}4.598^{* * * *} \\
(0.306) \\
\end{array}$ & $\begin{array}{c}4.599 * * * \\
(0.308) \\
\end{array}$ & $\begin{array}{c}6.112 * * * \\
(0.546) \\
\end{array}$ & $\begin{array}{c}4.564 * * * \\
(0.308) \\
\end{array}$ & $\begin{array}{c}4.563 * * * \\
(0.306) \\
\end{array}$ & $\begin{array}{c}6.183 * * * \\
(0.544) \\
\end{array}$ \\
\hline $\begin{array}{l}\text { Observations } \\
\text { Number of Persons }\end{array}$ & $\begin{array}{l}31,969 \\
11,512\end{array}$ & $\begin{array}{l}31,719 \\
11,449\end{array}$ & $\begin{array}{l}31,791 \\
11,470 \\
\end{array}$ & $\begin{array}{l}31,906 \\
11,492 \\
\end{array}$ & $\begin{array}{l}31,956 \\
11,509\end{array}$ & $\begin{array}{l}31,480 \\
11,388 \\
\end{array}$ \\
\hline $\begin{array}{l}\text { Tests } \\
\text { Arellano-Bond Test AR } 2 \\
\text { (p-value) }\end{array}$ & 0.915 & 0.968 & 0.605 & 0.903 & 0.866 & 0.489 \\
\hline Hansen J-Test (p-value) & 0.460 & 0.439 & 0.545 & 0.381 & 0.250 & 0.408 \\
\hline
\end{tabular}

*** $\mathrm{p}<0.001, * * \mathrm{p}<0.01, * \mathrm{p}<0.05, \# \mathrm{p}<0.10$; robust standard errors

sys GMM: System generalized method of moments; see Appendix A for discussion of the tests

Controls are: years of schooling, marital status, dummy for out of labor force; previous time in unemployment, current employment duration, gender, migration background, subsample dummy, dummies for survey wave/year;

Full regression tables can be found in the online, Table A3 
The third mechanism under investigation is social network composition (Models 4 and 5). After introducing either of our measures for weak and strong-tie social capital, the regression coefficient of unemployment on health only changes marginally. Similar to monetary resources, the potential loss of social resources due to unemployment does not explain the negative health effects of unemployment. And similar to monetary resources, social resources, too, do not have the expected effect on health. Hypothesis $2 \mathrm{c}$ is therefore not supported by the data. Finally, Model 6 includes all potential mechanism variables. As we can see, there are no surprises, and self-perceived social status remains the only mechanism significantly influencing health. ${ }^{10}$

We chose health satisfaction as our dependent variable because satisfaction on that 11-point scale is often observed to be useful in regression methods that assume cardinal scales. However, we replicated our results with self-rated health, measured on a five-point scale as well as a five-point scale measure for psychological health. The results are very similar across all three dependent variables (see appendix, Tables A4 and A5). For psychological health, self-perceived social status even explains nearly the whole negative coefficient of unemployment. However, we chose to report the results for health satisfaction in our main analysis because, for the latter, the tests of the system GMM estimator were better.

\section{Discussion and Conclusions}

Indirect selection due to common causes, direct selection of unhealthy workers into unemployment, and social causation are often proposed as three alternative explanations for the high correlation of ill health and unemployment incidence, even if they are not mutually exclusive. In this paper, we focused on identifying the social causation effect net of the confounding influence of both direct and indirect selection. We consider the empirical evidence that we presented to strongly support the social causation thesis. By applying several different panel regression methods, we first found that the negative relationship between unemployment and health is not explained by indirect selection on either observed or unobserved confounders. Second, by investigating the health trajectory before unemployment, we found evidence that the causal relationship between health and unemployment might at least be partly driven by direct selection of unhealthy individuals into unemployment. However, third, after applying an estimation method that accounted for both direct and indirect selection, we still found significant and negative causal effects of unemployment on health. We conclude not only that the fact that the unemployed are in worse

\footnotetext{
${ }^{10}$ Because of selective missing values in the mechanism variables, the number of cases varies between models. Usually, researchers would like to test the mechanisms on identical sample sizes, but in the case of the stata add-on xtabond2, this is not possible. However, model 5 fulfills a similar function in that it restricts the sample to cases that have no missing values in either mechanism variable.
} 
health than employed individuals cannot be attributed to direct or indirect selection effects alone but also that the magnitude of this health decline is quite large. However, we have to remain agnostic with regard to the existence and/or strength of the indirect selection effect.

To further explain the negative causal effect of unemployment on health, we three potential mechanisms that are often discussed in the literature, but were seldomly tested. Some researchers might find it surprising not only that household income and social contacts did not explain the unemployment - health relationship but also that the two variables were not associated with our health measure at all. Given that there is a large literature indicating the positive effects of both financial and social resources on health, this could indicate a problem with measurement error. We argue that this is not the case, but for reasons that are different for household income and social contacts. Starting with social contacts, the literature documents the positive effects of social contacts for job-finding, thus helping individuals to shorten or avoid unemployment episodes altogether (see e.g. Castilla et al. 2013) and also points out the potential for health influencing social networks (Thoits 2011:156). However, there is always a question of how to adequately measure social resources (Van Der Gaag et al. 2008). Because the system GMM estimator eliminated reverse causality bias from the coefficients, it is also possible that the insignificant coefficients are results of actual null effects of social resources. To distinguish between those two possibilities, we also included our weak and strong tie social capital indicators in a fixed-effects regression, that does not distinguish between causal directions. We found the fixed effects coefficient for strong tie social capital (number of close friends) to be statistically significant and the coefficient for the weak tie indicator (active membership in voluntary organizations) at least close to statistical significance (see appendix, table A6). Therefore, we are more inclined to accept the null effect as such, but acknowledge that other indicators of social embeddedness might lead to different results. For household income, the situation is different. In line with the literature, we found no significant effects neither in the system GMM, nor in the fixed-effects regression. We conclude that reverse causality is not a problem, at least in the short-term perspective of our analysis. But why are there no effects of household income. At least in the German context, from which the data of the above analysis are derived, the reason can probably be found in the health care system. In Germany, the unemployed are included in a system of nearly universal health insurance coverage, and out-of-pocket spending for health services is capped at $1 \%$ for low incomes (Schoen et al. 2010), which makes it plausible that health is independent of the loss of income, at least in the short term. However, from our analytical design, we can draw no conclusions as to the long-term effects of the loss of income on health.

Another important result of our analysis is that they point to the importance of self-perceived social status. Whereas this result is to our knowledge rather novel for quantitative analysis, it is in line with several, predominantly qualitative studies on the effect of unemployment. Such studies have, for example, 
documented the severe consequences of unemployment for the unemployed person's sense of identity (e.g., Morgenroth 2002; Rogge 2013), often pointing to the societal stigma attached to unemployment (Knabe, Fischer, and Klärner 2017, Hirseland and Ramos Lobato 2014). We found that self-perceived status loss explained a substantial part of the negative effect, but acknowledge that further research is necessary to corroborate this finding, possibly employing more comprehensive measures of individual's perceptions in terms of their social identity and where they see themselves in society. 


\section{References}

Allison, Paul D. 2009. Fixed Effects Regression Models. Los Angeles: Sage Publications.

Andreeva, Elena, Linda L. Magnusson Hanson, Hugo Westerlund, Töres Theorell, and M. Harvey Brenner. 2015. 'Depressive Symptoms as a Cause and Effect of Job Loss in Men and Women: Evidence in the Context of Organisational Downsizing from the Swedish Longitudinal Occupational Survey of Health." BMC Public Health 15(1): 1045.

Andreß, Hans-Jürgen, Katrin Golsch, and Alexander W. Schmidt. 2013. Applied Panel Data Analysis for Economic and Social Surveys. Berlin, Heidelberg: Springer.

Arellano, Manuel, and Olympia Bover. 1995. "Another Look at the Instrumental Variable Estimation of Error-Components Models.” Journal of Econometrics 68(1): 29-51.

Arellano, Manuel, and Stephen Bond. 1991. "Some Tests of Specification for Panel Data: Monte Carlo Evidence and an Application to Employment Equations." The Review of Economic Studies 58(2): 277.

Averett, Susan L., Laura M. Argys, and Jennifer C. Kohn. 2014. "Friends with Health Benefits: Does Individual-level Social Capital Improve Health?” Eastern Economic Journal 40(2): 181-201.

Bartley, Mel. 1988. “Unemployment and Health: Selection or Causation-a False Antithesis?” Sociology of Health \& Illness 10(1): 41-67.

Bartley, Mel. 1994. “Unemployment and Ill Health: Understanding the Relationship.” Journal of Epidemiology and Community Health 48(4): 333-337.

Baum, Christopher F., and Mark E. Schaffer. 2003. "Instrumental Variables and GMM: Estimation and Testing." STATA Journal 3(1): 1-31.

Berkman, Lisa. F., Thomas Glass, Ian Brissette, and Teresa E. Seeman. 2000. "From Social Integration to Health: Durkheim in the New Millennium." Social Science \& Medicine 51(6): 843-857.

Bethmann, Arne, Benjamin Fuchs, and Anja Wurdack (Eds.). 2013. User Guide Panel Study Labour Market and Social Security (PASS): Wave 6. (FDZ-Datenreport, 07/2013 (en)), Institute for Employment Research, Nuremberg.

Black, Sandra E., Paul J. Devereux, and Kjell G. Salvanes. 2015. "Losing Heart? The Effect of Job Displacement on Health.” ILR Review 68(4): 833-861.

Blundell, Richard, and Stephen Bond. 1998. "Initial Conditions and Moment Restrictions in Dynamic Panel Data Models.” Journal of Econometrics 87(1): 115-43.

Böckerman, Petri, and Pekka Ilmakunnas. 2009. "Unemployment and Self-Assessed Health: Evidence from Panel Data." Health Economics 18(2): 161-79.

Brand, Jennie E. 2015. "The Far-Reaching Impact of Job Loss and Unemployment.” Annual Review of Sociology 41: 359-75.

Brüderl, Josef, and Ludwig Volker. 2015. "Fixed-Effects Panel Regression." In The Sage Handbook of Regression Analysis and Causal Inference, edited by Henning Best and Christof Wolf, 327-358. Los Angeles: Sage Reference.

Castilla, Emilio J., George J. Lan, and Ben A. Rissing. 2013. "Social Networks and Employment: Outcomes (Part 2)." Sociology Compass 7(12): 1013-1026.

Cohen, Sheldon, Cuneyt M. Alper, William J. Doyle, Nancy Adler, N., John J. Treanor, and Ronald B. Turner. 2008. "Objective and subjective socioeconomic status and susceptibility to the common cold." Health Psychology 27: 268-274. 
Conti, Gabriella, James Heckman, and Sergio Urzua. 2010. "The education-health gradient." The American economic review 100(2): 234.

Contoyannis, Paul, Andrew M. Jones, and Nigel Rice. 2004. "The Dynamics of Health in the British Household Panel Survey." Journal of Applied Econometrics 19(4): 473-503.

Cook, Derek G. 1985. "A critical View of the Unemployment and Health Debate.” The Statistician 34(1): 73-82.

Cygan-Rehm, Kamila, Daniel Kuehnle, and Michael Oberfichtner. 2017. "Bounding the Causal Effect of Unemployment on Mental Health: Nonparametric Evidence from Four Countries.” Health economics: 118.

Demakakos, Panayotes, James Nazroo, Elizabeth Breeze, and Michael Marmot. 2008. "Socioeconomic Status and Health: the Role of Subjective Social Status." Social Science \& Medicine 67(2): 330-40.

Ferlander, Sara. 2007. “The Importance of Different Forms of Social Capital for Health.” Acta Sociologica 50(2): 115-128.

Ferrie, Jane E., Martin J. Shipley, Michael G. Marmot, Stephen Stansfeld, and Georg D. Smith. 1995. "Health Effects of Anticipation of Job Change and Non-Employment: Longitudinal Data from the Whitehall II Study." BMJ 311(7015): 1264-1269.

Foverskov, Else, and Anders Holm. 2016. "Socioeconomic Inequality in Health in the British Household Panel: Tests of the Social Causation, Health Selection and the Indirect Selection Hypothesis Using Dynamic Fixed Effects Panel Models." Social Science \& Medicine 150: 172-183.

Frijters, Paul, John P. Haisken-DeNew, and Michael A. Shields. 2005. "The Causal Effect of Income on Health: Evidence from German Reunification.” Journal of Health Economics 24(5): 997-1017.

Gebel, Michael, and Jonas Voßemer. 2014. "The Impact of Employment Transitions on Health in Germany. A Difference-in-Differences Propensity Score Matching Approach.” Social Science \& Medicine 108: 128-136.

Goldthorpe, John H. 2001. "Causation, Statistics, and Sociology.” European Sociological Review 17(1): $1-20$.

Granovetter, Mark S. 1973. "The Strength of Weak Ties.” American Journal of Sociology 78(6): 13601380 .

Grossman, Michael. 1972. "On the concept of health capital and the demand for health." Journal of Political economy 80(2): 223-255.

Gunasekara, Fiona I., Ken Richardson, Kristie Carter, and Tony Blakely. 2014. "Fixed Effects Analysis of Repeated Measures Data.” International Journal of Epidemiology 43(1): 264-269.

Gundert, Stefanie, and Christian Hohendanner. 2014. "Do Fixed-Term and Temporary Agency Workers Feel Socially Excluded? Labour Market Integration and Social Well-Being in Germany." Acta Sociologica 57(2): 135-152.

Halaby, Charles N. 2004. "Panel Models in Sociological Research: Theory into Practice." Annual Review of Sociology 30(1): 507-544.

Heggebø, Kristian. 2015. "Unemployment in Scandinavia during an Economic Crisis: Cross-National Differences in Health Selection.” Social Science \& Medicine 130: 115-124.

Hirseland, Andreas, and Philipp Ramos Lobato. 2014. "'Die wollen ja ein bestimmtes Bild vermitteln". Zur Neupositionierung von Hilfeempfängern im aktivierenden Sozialstaat." Social Science Open Access Repository 54(2): 181-200. 
Jackman, Mary. R., and Robert. W. Jackman. 1973. "An Interpretation of the Relation between Objective and Subjective Social Status.” American Sociological Review 38(5): 569-582.

Jahoda, Marie. 1981. "Work, Employment, and Unemployment: Values, Theories, and Approaches in Social Research.” American Psychologist 36(2): 184-191.

Janlert, Urban, and Anne Hammarström. 2009. "Which Theory Is Best? Explanatory Models of the Relationship between Unemployment and Health.” BMC Public Health 9(1): 235.

Jones, Loring P. 1988. "Unemployment and social integration: a review." The Journal of Sociology \& Social Welfare 15(4): 161-176.

Kessler, Ronald C., J. Blake Turner, and James S. House. 1987. "Intervening processes in the relationship between unemployment and health." Psychological Medicine 17: 949-961.

Knabe, André, Hagen Fischer, and Andreas Klärner. 2017. Armut als relationales Konstrukt: Die (Re)Produktion sozialer Ungleichheiten durch Stigmatisierung und Kontrollversuche in sozialen Netzwerken. In ,Doing Inequality، - Prozesse sozialer Ungleichheit im Blick qualitativer Sozialforschung, edited by Laura Behrmann, Falk Eckert, Andreas Gefken, and Peter A. Berger, 167-190. Wiesbaden: Springer VS.

Kokko, Katja, and Lea Pulkkinen. 1998. "Unemployment and Psychological Distress: Mediator Effects." Journal of Adult Development, 5(4): 205-217.

Korpi, Tomas. 2001. "Accumulating Disadvantage. Longitudinal Analyses of Unemployment and Physical Health in Representative Samples of the Swedish Population.” European Sociological Review 17(3): 255-273.

Kroll, Lars E., Stephan Müters, and Thomas Lampert. 2016. "Arbeitslosigkeit und ihre Auswirkungen auf die Gesundheit." Bundesgesundheitsblatt-Gesundheitsforschung-Gesundheitsschutz 59(2): 228-237.

Lindsay, Colin. 2009. "In a Lonely Place? Social Networks, Job Seeking and the Experience of LongTerm Unemployment." Social Policy and Society 9: 25-37.

Mandemakers, Jornt J., and Christiaan W. S. Monden. 2013. "Does the Effect of Job Loss on Psychological Distress Differ by Educational Level?” Work, Employment and Society 27(1): 73-93.

Marcus, Jan. 2014. “Does Job Loss Make You Smoke and Gain Weight?” Economica 81(324): 626-648.

McDonough, Peggy, and Benjamin C. Amick. 2001. "The Social Context of Health Selection: a Longitudinal Study of Health and Employment." Social Science \& Medicine 53(1): 135-145.

Meer, Jonathan, Douglas L. Miller, and Harvey S. Rosen. 2003. "Exploring the Health-Wealth Nexus." Journal of Health Economics 22(5): 713-730.

Mincer, Jacob. 1991. Education and unemployment. No. w3838. National bureau of economic research,

Minelli, Liliana, Claudia Pigini, Manuela Chiavarini, and Francesco Bartolucci. 2014. "Employment Status and Perceived Health Condition: Longitudinal Data from Italy." BMC Public Health 14: 946.

Morgenroth, Christine. 2002. "Depressive Dynamik in der Arbeitslosigkeit." In Transformation der Arbeit, edited by Tim Darmstädter, 135-152. Frankfurt a.M.: Verlag Neue Kritik.

Morris, J. K., and D. G. Cook. 1991. "A Critical Review of the Effect of Factory Closures on Health." Occupational and Environmental Medicine 48(1): 1-8.

Netuveli, Gopalakrishnan, and Mel Bartley. 2012. "Perception is Reality: Effect of Subjective Versus Objective Socio-economic Position on Quality of Life.” Sociology 46(6): 1208-1215.

Nickell, S. (1981). "Biases in Dynamic Models With Fixed Effects." Econometrica: Journal of the Econometric Society 49(6): 1417-1426. 
Oakes, J. Michael, and Peter H. Rossi. 2003. "The Measurement of SES in Health Research: Current Practice and Steps Toward a New Approach.” Social Science \& Medicine 56: 769-784.

Paul, Karsten I., and Klaus Moser. 2009. "Unemployment Impairs Mental Health: Meta-Analyses." Journal of Vocational Behavior 74(3): 264-282.

Paul, Karsten I., Eva Geithner, and Klaus Moser. 2009. "Latent deprivation among people who are employed, unemployed, or out of the labor force." The Journal of Psychology 143(5): 477-491.

Peacock, Marian, Paul Bissell, and Jenny Owen. 2014. "Shaming Encounters: Reflections on Contemporary Understandings of Social Inequality and Health.” Sociology 48(2): 387 -402.

Pearlin, Leonard I. 1989. “The Sociological Study of Stress.” Journal of Health and Social Behavior 30(3): 241-256.

Piper, Alan T. 2015. "Sliding Down the U-Shape? A Dynamic Panel Investigation of the Age-Well-Being Relationship, Focusing on Young Adults." Social Science \& Medicine 143: 54-61.

Rogge, Benedikt. 2013. Wie uns Arbeitslosigkeit unter die Haut geht. Identitätsprozess und psychische Gesundheit bei Statuswechseln. Konstanz: UVK-Verlagsgesellschaft.

Roodman, David. 2009a. “A Note on the Theme of Too Many Instruments." Oxford Bulletin of Economics and Statistics 71(1): 135-158.

Roodman, David. 2009b. "How to do Xtabond2: An Introduction to Difference and System GMM in Stata." STATA Journal 9(1): 86-136.

Ruiter, Stijn and Nan D. De Graaf. 2009. "Socio-Economic Payoffs of Voluntary Association Involvement: A Dutch Life Course Study.” European Sociological Review 25(4): 425-442.

Salm, Martin. 2009. “Does Job Loss Cause Ill Health?” Health Economics 18(9): 1075-1089.

Schmitz, Hendrik. 2011. "Why are the Unemployed in Worse Health? The Causal Effect of Unemployment on Health." Labour Economics 18(1): 71-78.

Schoen, Cathy, Robin Osborn, David Squires, Michelle M. Doty, Roz Pierson, and Sandra Applebaum. 2010. "How Health Insurance Design Affects Access To Care And Costs, By Income, In Eleven Countries“. Health Affairs 29(12): 2323-2334.

Stewart, Jennifer M. 2001. "The Impact of Health Status on the Duration of Unemployment Spells and the Implications for Studies of the Impact of Unemployment on Health Status." Journal of Health Economics 20(5): 781-796.

Strully, Kate W. 2009. "Job loss and Health in the US Labor Market.” Demography 46(2): 221-246.

Thoits, Peggy. A. 2011. "Mechanisms linking social ties and support to physical and mental health." Journal of Health and Social Behavior 52(2): 145-161.

Tøge, Anne G., and Morten Blekesaune. 2015. "Unemployment Transitions and Self-Rated Health in Europe: a Longitudinal Analysis of EU-SILC from 2008 to 2011." Social Science \& Medicine 143: 171178.

Trappmann, Mark, Jonas Beste, Arne Bethmann, and Gerrit Müller. 2013. "The PASS panel survey after six waves". Journal for Labour Market Research 46(4):275-281.

Vaisey, Stephen, and Andrew Miles. 2017 "What You Can—and Can't—Do With Three-Wave Panel Data." Sociological Methods \& Research 46(1): 44-67.

Van Der Gaag M., Webber M. 2008. „Measurement of Individual Social Capital.” In: Kawachi I., Subramanian S., Kim D. (eds) Social Capital and Health. Springer, New York, NY 
Virtanen, Marianna, Mika Kivimäki, J. Vahtera, Marko Elovainio, Reijo Sund, P. Virtanen, and Jane E. Ferrie. 2006. "Sickness Absence as a Risk Factor for Job Termination, Unemployment, and Disability Pension among Temporary and Permanent Employees." Occupational and Environmental Medicine 63(3): 212-217.

Wanberg, Connie R. 2012. "The Individual Experience of Unemployment.” Annual Review of Psychology 63: 369-396.

West, Patrick. 1991. "Rethinking the Health Selection Explanation for Health Inequalities." Social Science \& Medicine 32(4): 373-384.

Wolbers, Maarten H. J. 2000. "The effects of level of education on mobility between employment and unemployment in the Netherlands." European Sociological Review 16(2): 185-200.

Wolff, Lisa S., S. V. Subramanian, Dolores Acevedo-Garcia, Deanne Weber, and Ichiro Kawachi. 2010. "Compared to Whom? Subjective Social Status, Self-Rated Health, and Referent Group Sensitivity in a Diverse US Sample.” Social Science \& Medicine 70(12): 2019-2028.

Young, Cristobal. 2012. "Losing a Job: The Nonpecuniary Cost of Unemployment in the United States." Social Forces 91(2): 609-634. 


\section{Appendix: Statistical tests and sensitivity checks}

The results presented above support the social causation thesis. This support is, to a large extent, based on eliminating potential bias due to reverse causality in the coefficients from the fixed-effects regression. This is done by applying a system GMM estimator. Therefore, we performed a variety of tests regarding key assumptions of this estimator. First, we conducted the Wooldridge test for serial correlation. The hypothesis of no serial correlation was rejected at a p-value of 0.000 , thus indicating the necessity to include lagged dependent variables. Because any remaining serial correlation, even after including the lags of the dependent variables, would invalidate the instrumental variable approach, an Arrelano/Bond - test is conducted. The test indicates that if two lags of the dependent variable are included, the null hypothesis of second-order serial correlation can be rejected for all our regression models. In the System GMM, negative first-order serial correlation is inherent, whereas second-order serial correlation must be avoided. Second, the Hansen J-test for the joint validity of all the instruments is conducted. Its p-value should be larger than 0.1, or better yet, larger than 0.25 (Roodman 2009a), thus indicating that the null hypothesis of joint validity is not rejected. The Hansen J-tests in Table 2 are all insignificant, and p-values range between 0.25 and 0.55 . Because The Hansen J-test loses power with too many instruments relative to the sample size, we keep the number of instruments in our analysis to a minimum, using only two lags. There are no definitive thresholds; research indicates that in applications where instrument count is close, the number of observations is problematic. In our sample of more than 30,000 observations and - at maximum - 205 instruments, the problem seems negligible. Our results are not sensitive with respect to the number of lags or instruments (see Table A7 for results with 3 laggs for internal instrumentation).

A further assumption is that all individuals are close to their long-run mean with respect to the instrumented variables. For example, in terms of health, this assumption means that individuals are (rather unrealistically) becoming more and more healthy each year or that their health (somewhat more realistically) is continuing to decline, net of all covariate influences. The latter condition does not exclude health shocks due to unemployment or divorce, or to the influence of age, but it means that if those factors are controlled for, the individual's "usual" health level should not exhibit any time trends. We argue that the main reasons for (negative) health trends are controlled for in our analysis (e.g., unemployment duration and age). Still, a plausibility check could be to exclude individuals aged older than 55 from the analysis, assuming that individuals older than 55 are more likely to experience continuously deteriorating health. This check does not substantially change our results (see Table A7 in the appendix). 
Table A 1: Descriptives by wave

\begin{tabular}{|c|c|c|c|c|c|c|c|c|c|c|c|}
\hline & \multicolumn{2}{|c|}{$\begin{array}{l}\text { Wave } 1 \\
(2007)\end{array}$} & \multirow{2}{*}{$\begin{array}{c}\text { Wave } \\
2 \\
(2008) \\
\end{array}$} & \multirow{2}{*}{$\begin{array}{c}\text { Wave } \\
3 \\
(2009) \\
\end{array}$} & \multirow{2}{*}{$\begin{array}{c}\text { Wave } \\
4 \\
(2010) \\
\end{array}$} & \multirow{2}{*}{$\begin{array}{c}\text { Wave } \\
5 \\
(2011) \\
\text { Mean }\end{array}$} & \multirow{2}{*}{$\begin{array}{c}\text { Wave } \\
6 \\
(2012) \\
\end{array}$} & \multirow{2}{*}{$\begin{array}{c}\text { Wave } \\
7 \\
(2013) \\
\end{array}$} & \multirow{2}{*}{$\begin{array}{c}\text { Wave } \\
8 \\
(2014) \\
\end{array}$} & \multicolumn{2}{|c|}{$\begin{array}{c}\text { Waves } \\
1-8\end{array}$} \\
\hline & Mean & $\begin{array}{l}\text { Std. } \\
\text { Dev }\end{array}$ & & & & & & & & $\begin{array}{l}\mathrm{Mi} \\
\mathrm{n}\end{array}$ & $\begin{array}{l}\mathrm{M} \\
\mathrm{ax}\end{array}$ \\
\hline Health satisfaction & 6.86 & 2.43 & 6.81 & 6.82 & 6.85 & 6.90 & 6.77 & 6.75 & 6.76 & 0 & 10 \\
\hline Self-rated health & 3.43 & 1.03 & 3.39 & 3.36 & 3.36 & 3.38 & 3.32 & 3.22 & 3.28 & 1 & 5 \\
\hline Psychological health & 3.83 & 1.27 & 3.89 & 3.86 & 3.83 & 3.87 & 3.81 & 3.78 & 3.82 & 1 & 5 \\
\hline Employed & 0.48 & & 0.53 & 0.57 & 0.6 & 0.61 & 0.62 & 0.63 & 0.65 & 0 & 1 \\
\hline Unemployed & 0.36 & & 0.38 & 0.35 & 0.32 & 0.30 & 0.29 & 0.28 & 0.27 & 0 & 1 \\
\hline Out of labor force & 0.16 & & 0.09 & 0.08 & 0.08 & 0.09 & 0.09 & 0.09 & 0.08 & 0 & 1 \\
\hline Age & 41.81 & $\begin{array}{r}10.7 \\
9 \\
\end{array}$ & 41.97 & 41.87 & 42.12 & 42.56 & 42.54 & 42.58 & 42.45 & 16 & 64 \\
\hline Education (years) & 12.03 & 2.67 & 11.96 & 12.05 & 12.01 & 11.99 & 12.00 & 12.08 & 12.16 & 7 & 21 \\
\hline Married & 0.53 & & 0.47 & 0.45 & 0.44 & 0.45 & 0.45 & 0.44 & 0.42 & 0 & 1 \\
\hline Number of children & 1.53 & 1.29 & 1.44 & 1.43 & 1.44 & 1.42 & 1.44 & 1.43 & 1.40 & 0 & 16 \\
\hline $\begin{array}{l}\text { Previous time spent } \\
\text { in employment } \\
\text { (month) }\end{array}$ & 194.28 & $\begin{array}{r}144 . \\
32\end{array}$ & 192.07 & 189.28 & 188.36 & 192.48 & 190.73 & 190.40 & 189.96 & 0 & 806 \\
\hline $\begin{array}{l}\text { Previous time spent } \\
\text { in unemployment } \\
\text { (month) }\end{array}$ & 31.88 & $\begin{array}{r}47.5 \\
5\end{array}$ & 36.39 & 36.55 & 39.37 & 40.60 & 39.95 & 40.18 & 39.38 & 0 & 701 \\
\hline Female & 0.57 & & 0.54 & 0.55 & 0.54 & 0.54 & 0.54 & 0.53 & 0.54 & 0 & 1 \\
\hline $\begin{array}{l}\text { Migration } \\
\text { background }\end{array}$ & 0.20 & & 0.21 & 0.21 & 0.22 & 0.23 & 0.24 & 0.23 & 0.24 & 0 & 1 \\
\hline Sample & 0.48 & & 0.53 & 0.56 & 0.61 & 0.59 & 0.62 & 0.65 & 0.67 & 0 & 1 \\
\hline $\begin{array}{l}\text { Household income } \\
\text { (in } 100 € \text { ) }\end{array}$ & 19.64 & $\begin{array}{r}13.9 \\
2 \\
\end{array}$ & 20.72 & 20.43 & 20.38 & 21.38 & 21.89 & 22.30 & 22.69 & & $\begin{array}{c}100 \\
0\end{array}$ \\
\hline $\begin{array}{l}\text { Self-perceived } \\
\text { Social Status at } \mathrm{t}_{0} \\
(\text { low }=10)\end{array}$ & 3.73 & 1.99 & 3.74 & 3.60 & 3.59 & 3.53 & 3.52 & 3.44 & 3.35 & 1 & 10 \\
\hline Strong Ties & 8.51 & 8.65 & 8.12 & 7.06 & 7.25 & 7.22 & 7.29 & 7.05 & 7.05 & 0 & 99 \\
\hline Weak Ties & 0.28 & & 0.26 & 0.26 & 0.27 & 0.28 & 0.27 & 0.26 & 0.27 & 0 & 1 \\
\hline Observations & 7,197 & & 8,104 & 8,641 & 7,796 & 10,271 & 9,536 & 9,444 & 8,745 & & \\
\hline
\end{tabular}


Table A 2: Full regression tables for results presented in Table 1

\begin{tabular}{|c|c|c|c|c|c|c|}
\hline & Model (1) & Model (2) & Model (3) & Model (4) & Model (5) & Model (6) \\
\hline & Pooled OLS & FE & FE & FE & sysGMM & sysGMM \\
\hline & $\begin{array}{c}\text { Coeff } \\
\text { (std.err) }\end{array}$ & $\begin{array}{l}\text { Coeff } \\
\text { (std.err) }\end{array}$ & $\begin{array}{l}\text { Coeff } \\
\text { (std.err) }\end{array}$ & $\begin{array}{l}\text { Coeff } \\
\text { (std.err) }\end{array}$ & $\begin{array}{c}\text { Coeff } \\
\text { (std.err) }\end{array}$ & $\begin{array}{c}\text { Coeff } \\
\text { (std.err) }\end{array}$ \\
\hline Unemployed at $t_{0}$ & $\begin{array}{l}-0.827 * * * \\
(0.0331)\end{array}$ & $\begin{array}{l}-0.248 * * * \\
(0.0314)\end{array}$ & & & $\begin{array}{l}-0.573 * * * \\
(0.104)\end{array}$ & \\
\hline $\begin{array}{l}\text { Unemployment } \\
\text { duration (in } \\
\text { month) at } \mathrm{t}_{0}\end{array}$ & & & $(0.000570)$ & & & $(0.00114)$ \\
\hline $\begin{array}{l}>=2 \text { years prior } \\
\text { to unemployment } \\
\text { (employed) }\end{array}$ & & & & $0.211 * * *$ & & \\
\hline $\begin{array}{l}1 \text { year prior to } \\
\text { unemployment } \\
\text { (employed) }\end{array}$ & & & & $\begin{array}{l}(0.0605) \\
0.0588\end{array}$ & & \\
\hline $\begin{array}{l}\text { Reference } 1^{\text {st }} \\
\text { year of } \\
\text { unemployment) }\end{array}$ & & & & $(0.0469)$ & & \\
\hline $\begin{array}{l}\text { 2nd year of } \\
\text { unemployment }\end{array}$ & & & & $-0.181^{*}$ & & \\
\hline $\begin{array}{l}>2 \text { nd year of } \\
\text { unemployment }\end{array}$ & & & & $\begin{array}{l}(0.0723) \\
-0.220 * \\
(0.0955)\end{array}$ & & \\
\hline $\begin{array}{l}\text { Out of labor force } \\
\text { at t0 }\end{array}$ & $\begin{array}{l}-0.100 * \\
(0.0464)\end{array}$ & $\begin{array}{l}0.0153 \\
(0.0454)\end{array}$ & & $\begin{array}{l}0.136 * * * \\
(0.0396)\end{array}$ & $\begin{array}{l}-0.0969 \\
(0.143)\end{array}$ & \\
\hline $\begin{array}{l}\text { Age (centered) at } \\
\text { t0 }\end{array}$ & $\begin{array}{l}-0.0458 * * * \\
(0.00220)\end{array}$ & & & & $\begin{array}{l}-0.0303 * * * \\
(0.00750)\end{array}$ & $\begin{array}{l}-0.0304 * * * \\
(0.00569)\end{array}$ \\
\hline $\begin{array}{l}\text { Education (years) } \\
\text { at t0 }\end{array}$ & $\begin{array}{l}0.0785 * * * \\
(0.00514)\end{array}$ & $\begin{array}{l}0.0429^{*} \\
(0.0205)\end{array}$ & $\begin{array}{l}0.0408 * \\
(0.0205)\end{array}$ & $\begin{array}{l}0.0414 * \\
(0.0207)\end{array}$ & $\begin{array}{l}0.0483 * * * \\
(0.00708)\end{array}$ & $\begin{array}{l}0.0494 * * * \\
(0.00615)\end{array}$ \\
\hline $\begin{array}{l}\text { Married at t0 (R: } \\
\text { no) }\end{array}$ & $\begin{array}{l}0.0910 * * \\
(0.0314)\end{array}$ & $\begin{array}{l}0.0145 \\
(0.0533)\end{array}$ & $\begin{array}{l}0.0196 \\
(0.0540)\end{array}$ & $\begin{array}{l}0.0183 \\
(0.0458)\end{array}$ & $\begin{array}{l}0.0499 \\
(0.0346)\end{array}$ & $\begin{array}{l}0.0355 \\
(0.0321)\end{array}$ \\
\hline $\begin{array}{l}\text { Number of } \\
\text { children at t0 }\end{array}$ & $\begin{array}{l}0.0163 \\
(0.0123)\end{array}$ & $\begin{array}{l}0.0154 \\
(0.0196)\end{array}$ & $\begin{array}{l}0.0239 \\
(0.0197)\end{array}$ & $\begin{array}{l}0.0137 \\
(0.0171)\end{array}$ & $\begin{array}{l}0.0162 \\
(0.0122)\end{array}$ & $\begin{array}{l}0.0213 \# \\
(0.0125)\end{array}$ \\
\hline $\begin{array}{l}\text { Previous time } \\
\text { spent in } \\
\text { employment } \\
\text { (month) at t0 }\end{array}$ & $0.000321 \#$ & -0.00172 & -0.00125 & $-0.00143 \#$ & 0.000426 & 0.000638 \\
\hline $\begin{array}{l}\text { Previous time } \\
\text { spent in }\end{array}$ & $\begin{array}{l}(0.000173) \\
-0.00307 * * *\end{array}$ & $\begin{array}{l}(0.00110) \\
-0.00155\end{array}$ & $\begin{array}{l}(0.00115) \\
0.000635\end{array}$ & $\begin{array}{l}(0.000822) \\
-0.000840\end{array}$ & $\begin{array}{l}(0.000686) \\
-0.00301 * *\end{array}$ & $\begin{array}{l}(0.000466) \\
-0.00298 * * *\end{array}$ \\
\hline
\end{tabular}




\begin{tabular}{|c|c|c|c|c|c|c|}
\hline & $(0.000362)$ & $(0.00131)$ & $(0.00136)$ & (0.000994) & $(0.000939)$ & $(0.000843)$ \\
\hline \multirow[t]{2}{*}{ Female (R: male) } & 0.000135 & & & & 0.0274 & 0.0263 \\
\hline & $(0.0279)$ & & & & $(0.0334)$ & $(0.0340)$ \\
\hline \multirow{2}{*}{$\begin{array}{l}\text { Migration } \\
\text { background (R: } \\
\text { no) }\end{array}$} & $-0.0618 \#$ & & & & $-0.101 * *$ & $-0.0947^{*}$ \\
\hline & $(0.0333)$ & & & & $(0.0383)$ & $(0.0377)$ \\
\hline \multirow[t]{2}{*}{ Sample (R: no) } & $-0.290 * * *$ & & & & $-0.135 * * *$ & $-0.147 * * *$ \\
\hline & $(0.0312)$ & & & & $(0.0392)$ & $(0.0382)$ \\
\hline \multirow{2}{*}{$\begin{array}{l}\text { Wave } 2 \\
(2007 / 2008)\end{array}$} & 0.00557 & -0.0216 & -0.0226 & -0.0193 & & \\
\hline & $(0.0287)$ & $(0.0286)$ & $(0.0291)$ & $(0.0273)$ & & \\
\hline \multirow{2}{*}{$\begin{array}{l}\text { Wave } 3 \\
(2008 / 2009)\end{array}$} & -0.00584 & $-0.0628 \#$ & $-0.0669 \#$ & $-0.0535 \#$ & & \\
\hline & $(0.0301)$ & $(0.0348)$ & $(0.0358)$ & $(0.0305)$ & 0.0170 & 0.0231 \\
\hline \multirow[t]{2}{*}{ Wave 4 (2010) } & 0.0407 & -0.0561 & -0.0688 & -0.0427 & $(0.0313)$ & $(0.0316)$ \\
\hline & $(0.0322)$ & $(0.0451)$ & $(0.0467)$ & $(0.0371)$ & 0.0501 & $0.0594 \#$ \\
\hline \multirow[t]{2}{*}{ Wave 5 (2011) } & $0.0909 * *$ & -0.0332 & -0.0558 & -0.0141 & $(0.0306)$ & $(0.0304)$ \\
\hline & $(0.0320)$ & $(0.0544)$ & $(0.0565)$ & $(0.0434)$ & $-0.0653 *$ & -0.0477 \\
\hline \multirow[t]{2}{*}{ Wave 6 (2012) } & -0.0372 & $-0.191 * *$ & $-0.216 * * *$ & $-0.168 * * *$ & $(0.0305)$ & $(0.0303)$ \\
\hline & $(0.0328)$ & $(0.0629)$ & $(0.0655)$ & $(0.0496)$ & $-0.0745^{*}$ & $-0.0504 \#$ \\
\hline \multirow[t]{2}{*}{ Wave 7 (2013) } & -0.0541 & $-0.225^{* *}$ & $-0.256 * * *$ & $-0.198 * * *$ & $(0.0294)$ & $(0.0287)$ \\
\hline & $(0.0331)$ & $(0.0731)$ & $(0.0762)$ & $(0.0570)$ & -0.0454 & -0.0207 \\
\hline \multirow[t]{2}{*}{ Wave 8 (2014) } & $-0.0679 *$ & $-0.247 * *$ & $-0.283 * *$ & $-0.216 * * *$ & $(0.0303)$ & $(0.0294)$ \\
\hline & $(0.0339)$ & $(0.0834)$ & $(0.0869)$ & $(0.0646)$ & 0.0170 & 0.0231 \\
\hline \multirow[t]{2}{*}{ Constant } & $6.236 * * *$ & $6.843 * * *$ & $6.673 * * *$ & $6.670 * * *$ & $4.598 * * *$ & $4.426 * * *$ \\
\hline & $(0.101)$ & $(0.345)$ & $(0.354)$ & $(0.305)$ & $(0.306)$ & $(0.236)$ \\
\hline Observations & 69,734 & 69,734 & 68,608 & 69,734 & 31,969 & 31,647 \\
\hline R-squared & 0.138 & 0.007 & 0.006 & 0.006 & & \\
\hline Number of pnr & & 21,063 & 20,852 & 21,063 & 11,512 & 11,403 \\
\hline
\end{tabular}

Robust standard errors in parentheses; *** $\mathrm{p}<0.001, * * \mathrm{p}<0.01, * \mathrm{p}<0.05, \# \mathrm{p}<0.10$ 
Table A 3: Full regression tables for results presented in Table 2

\begin{tabular}{|c|c|c|c|c|c|c|c|}
\hline & Model (1) & Model (2) & Model (3) & Model (4) & Model (5) & Model (6) & Model (7) \\
\hline & sysGMM & sysGMM & sysGMM & sysGMM & sysGMM & sysGMM & sysGMM \\
\hline & $\begin{array}{c}\text { Coeff } \\
\text { (std.err) }\end{array}$ & $\begin{array}{l}\text { Coeff } \\
\text { (std.err) }\end{array}$ & $\begin{array}{l}\text { Coeff } \\
\text { (std.err) }\end{array}$ & $\begin{array}{c}\begin{array}{c}\text { Coeff } \\
\text { (std.err) }\end{array} \\
\end{array}$ & $\begin{array}{c}\text { Coeff } \\
\text { (std.err) }\end{array}$ & $\begin{array}{c}\text { Coeff } \\
\text { (std.err) }\end{array}$ & $\begin{array}{c}\text { Coeff } \\
\text { (std.err) }\end{array}$ \\
\hline Health at $t_{-1}$ & $\begin{array}{c}0.195 * * * \\
(0.0165)\end{array}$ & $\begin{array}{c}0.200^{* * *} \\
(0.0170)\end{array}$ & $\begin{array}{c}0.195^{* * *} \\
(0.0164)\end{array}$ & $\begin{array}{l}0.188 * * * \\
(0.0169)\end{array}$ & $\begin{array}{c}0.196 * * * \\
(0.0165)\end{array}$ & $\begin{array}{c}0.198^{* * *} \\
(0.0166)\end{array}$ & $\begin{array}{c}0.192 * * * \\
(0.0168)\end{array}$ \\
\hline Health at $t_{-2}$ & $\begin{array}{c}0.0779 * * * \\
(0.0131)\end{array}$ & $\begin{array}{c}0.0811 * * * \\
(0.0136)\end{array}$ & $\begin{array}{c}0.0781 * * * \\
(0.0131)\end{array}$ & $\begin{array}{c}0.0723 * * * \\
(0.0134)\end{array}$ & $\begin{array}{c}0.0777 * * * \\
(0.0132)\end{array}$ & $\begin{array}{c}0.0790 * * * \\
(0.0133)\end{array}$ & $\begin{array}{c}0.0766 * * * \\
(0.0134)\end{array}$ \\
\hline Unemployed at $t_{0}$ & $\begin{array}{c}-0.573 * * * \\
(0.104)\end{array}$ & & $\begin{array}{c}-0.582 * * * \\
(0.106)\end{array}$ & $\begin{array}{l}-0.315^{*} \\
(0.131)\end{array}$ & $\begin{array}{c}-0.558 * * * \\
(0.104)\end{array}$ & $\begin{array}{c}-0.600 * * * \\
(0.105)\end{array}$ & $\begin{array}{c}-0.337 * * \\
(0.126)\end{array}$ \\
\hline $\begin{array}{l}\text { Unemployment duration } \\
\text { (month) at } \mathrm{t}_{0}\end{array}$ & & $\begin{array}{c}- \\
0.00676 * * * \\
(0.00114)\end{array}$ & & & & & \\
\hline Out of labor force at $t_{0}$ & $\begin{array}{l}-0.0969 \\
(0.143)\end{array}$ & & $\begin{array}{l}-0.0957 \\
(0.143)\end{array}$ & $\begin{array}{l}-0.0644 \\
(0.145)\end{array}$ & $\begin{array}{l}-0.102 \\
(0.147)\end{array}$ & $\begin{array}{l}-0.0815 \\
(0.143)\end{array}$ & $\begin{array}{l}-0.0411 \\
(0.150)\end{array}$ \\
\hline Age (centered) at $t_{0}$ & $\begin{array}{c}- \\
0.0303 * * * \\
(0.00750)\end{array}$ & $-0.0304 * * *$ & $\begin{array}{c}- \\
0.0308 * * * \\
(0.00755)\end{array}$ & $\begin{array}{c}- \\
0.0298 * * * \\
(0.00749)\end{array}$ & $\begin{array}{c}- \\
0.0304 * * * \\
(0.00744)\end{array}$ & $\begin{array}{c}- \\
0.0314 * * * \\
(0.00753)\end{array}$ & $\begin{array}{c}- \\
0.0327 * * * \\
(0.00761)\end{array}$ \\
\hline Education (years) at $t_{0}$ & $\begin{array}{l}0.0483 * * * \\
(0.00708)\end{array}$ & $\begin{array}{l}0.0494 * * * \\
(0.00615)\end{array}$ & $\begin{array}{r}0.0514 * * * \\
(0.00834)\end{array}$ & $\begin{array}{l}0.0349 * * * \\
(0.00769)\end{array}$ & $\begin{array}{l}0.0480 * * * \\
(0.00741)\end{array}$ & $\begin{array}{l}0.0520 * * * \\
(0.00783)\end{array}$ & $\begin{array}{r}0.0467 * * * \\
(0.00908)\end{array}$ \\
\hline Married at $\mathrm{t}_{0}(\mathrm{R}: \mathrm{no})$ & $\begin{array}{c}0.0499 \\
(0.0346)\end{array}$ & $\begin{array}{c}0.0355 \\
(0.0321)\end{array}$ & $\begin{array}{c}0.0601 \\
(0.0433)\end{array}$ & $\begin{array}{l}-0.00276 \\
(0.0374)\end{array}$ & $\begin{array}{c}0.0482 \\
(0.0348)\end{array}$ & $\begin{array}{l}0.0581 \# \\
(0.0349)\end{array}$ & $\begin{array}{c}0.0378 \\
(0.0456)\end{array}$ \\
\hline Number of children at $t_{0}$ & $\begin{array}{c}0.0162 \\
(0.0122)\end{array}$ & $\begin{array}{l}0.0213 \# \\
(0.0125)\end{array}$ & $\begin{array}{c}0.0186 \\
(0.0130)\end{array}$ & $\begin{array}{c}0.0149 \\
(0.0120)\end{array}$ & $\begin{array}{c}0.0158 \\
(0.0126)\end{array}$ & $\begin{array}{c}0.0159 \\
(0.0122)\end{array}$ & $\begin{array}{l}0.0225 \# \\
(0.0131)\end{array}$ \\
\hline $\begin{array}{l}\text { Previous time spent in } \\
\text { employment (month) at } t_{0}\end{array}$ & $\begin{array}{l}0.000426 \\
(0.000686)\end{array}$ & 0.000638 & 0.000463 & 0.000501 & $\begin{array}{l}0.000435 \\
(0.000686)\end{array}$ & $\begin{array}{l}0.000542 \\
(0.000689)\end{array}$ & $\begin{array}{r}0.000741 \\
(0.000703)\end{array}$ \\
\hline $\begin{array}{l}\text { Previous time spent in } \\
\text { unemployment (month) at } \\
t_{0}\end{array}$ & $0.00301 * *$ & $0.00298 * * *$ & $0.00309 * *$ & $-0.00214 *$ & $0.00307 * *$ & $0.00280^{* *}$ & $-0.00216^{*}$ \\
\hline & $(0.000939)$ & $(0.000843)$ & $(0.000949)$ & $(0.000962)$ & $(0.000941)$ & $(0.000938)$ & $(0.000967)$ \\
\hline Female (R: male) & $\begin{array}{c}0.0274 \\
(0.0334)\end{array}$ & $\begin{array}{c}0.0263 \\
(0.0340)\end{array}$ & $\begin{array}{c}0.0268 \\
(0.0333)\end{array}$ & $\begin{array}{c}-0.00865 \\
(0.0335)\end{array}$ & $\begin{array}{c}0.0272 \\
(0.0338)\end{array}$ & $\begin{array}{c}0.0209 \\
(0.0340)\end{array}$ & $\begin{array}{l}-0.0184 \\
(0.0347)\end{array}$ \\
\hline $\begin{array}{l}\text { Migration background (R: } \\
\text { no) }\end{array}$ & $-0.101 * *$ & $-0.0947 *$ & $-0.108 * *$ & -0.0444 & $-0.103 * *$ & $-0.114 * *$ & -0.0741 \\
\hline Sample (R: no) & $\begin{array}{c}(0.0383) \\
-0.135^{* * *} \\
(0.0392)\end{array}$ & $\begin{array}{c}(0.0377) \\
-0.147 * * * \\
(0.0382)\end{array}$ & $\begin{array}{l}(0.0395) \\
-0.146 * * \\
(0.0504)\end{array}$ & $\begin{array}{l}(0.0410) \\
-0.0112 \\
(0.0531)\end{array}$ & $\begin{array}{c}(0.0387) \\
-0.136^{* * *} \\
(0.0390)\end{array}$ & $\begin{array}{c}(0.0425) \\
-0.158 * * * \\
(0.0437)\end{array}$ & $\begin{array}{l}(0.0451) \\
-0.0836 \\
(0.0590)\end{array}$ \\
\hline
\end{tabular}

Reference: Wave 3

(2009)

Wave 4 (2010)

0.0248

0.0107

0.0164

0.0203

0.0178

(0.0313)

(0.0316)

(0.0316)

(0.0317)

$(0.0317)$

(0.0314)

(0.0328)

0.0501

0.0594\#

0.0533\#

0.0132

0.0518

$0.0633 *$

0.0303

$(0.0306)$

$(0.0304)$

(0.0311)

$(0.0305)$

(0.0331)

$(0.0324)$

(0.0308)

(0.0352)

$(0.0303)$

$-0.0607 \#$

- $0.105 * *$

$0.0626 \#$

(0568\#

$-0.0844 *$

$-0.0745^{*}$

(0.0323)

$-0.0504 \#$

(0.0325)

$(0.0305)$

(0.0371)

(0.0294)

$(0.0287)$

$-0.124 * * *$

$-0.0738^{*}$

$-0.0692 *$

$-0.101^{* *}$

$-0.0454$

(0.0326)

(0.0312)

(0.0294)

$(0.0361)$

(0.0303)

(0.0294)

$-0.0373$

$-0.115^{* *}$

$-0.0428$

$-0.0379$

$-0.0892^{*}$

(0.0335)

(0.0369)

(0.0312)

(0.0303)

(0.0388)

$-0.00670$ 
$100 €)$ at $\mathrm{t}_{0}$

Self-perceived Social

$(0.00398)$

$\begin{array}{ll} & (0.00445) \\ -0.260 * * * & -0.280 * * *\end{array}$

Status at $\mathrm{t}_{0}(\mathrm{low}=10)$

(0.0752) (0.0709)

Strong Ties at $\mathrm{t}_{0}$

$0.00443 \quad 0.00330$

Weak Ties at $\mathrm{t}_{0}$

$(0.0174) \quad(0.0149)$

\begin{tabular}{|c|c|c|c|c|c|c|c|}
\hline Weak 11es at $t_{0}$ & & & & & & $\begin{array}{l}-0.192 \\
(0.172)\end{array}$ & $\begin{array}{c}-0.243 \\
(0.168)\end{array}$ \\
\hline Constant & $\begin{array}{c}4.598 * * * \\
(0.306)\end{array}$ & $\begin{array}{c}4.426 * * * \\
(0.236)\end{array}$ & $\begin{array}{c}4.599 * * * \\
(0.308)\end{array}$ & $\begin{array}{c}6.112 * * * \\
(0.546)\end{array}$ & $\begin{array}{c}4.564 * * * \\
(0.308)\end{array}$ & $\begin{array}{c}4.563 * * * \\
(0.306)\end{array}$ & $\begin{array}{c}6.183 * * * \\
(0.544)\end{array}$ \\
\hline Observations & 31,969 & 31,647 & 31,719 & 31,791 & 31,906 & 31,956 & 31,480 \\
\hline Number of persons & 11,512 & 11,403 & 11,449 & 11,470 & 11,492 & 11,509 & 11,388 \\
\hline
\end{tabular}

Robust standard errors in parentheses; *** $\mathrm{p}<0.001, * * \mathrm{p}<0.01, * \mathrm{p}<0.05, \# \mathrm{p}<0.10$

Table A 4: Results for self-rated health (equivalent to Table 2)

\begin{tabular}{|c|c|c|c|c|c|c|c|}
\hline & Model (1) & Model (2) & Model (3) & Model (4) & Model (5) & Model (6) & Model (7) \\
\hline & sysGMM & sysGMM & sysGMM & sysGMM & sysGMM & sysGMM & sysGMM \\
\hline & $\begin{array}{c}\text { Coeff } \\
\text { (std.err) }\end{array}$ & $\begin{array}{c}\text { Coeff } \\
\text { (std.err) }\end{array}$ & $\begin{array}{c}\text { Coeff } \\
\text { (std.err) }\end{array}$ & $\begin{array}{c}\text { Coeff } \\
\text { (std.err) }\end{array}$ & $\begin{array}{c}\text { Coeff } \\
\text { (std.err) }\end{array}$ & $\begin{array}{c}\text { Coeff } \\
\text { (std.err) }\end{array}$ & $\begin{array}{c}\text { Coeff } \\
\text { (std.err) }\end{array}$ \\
\hline Covariates & $\checkmark$ & $\checkmark$ & $\checkmark$ & $\checkmark$ & $\checkmark$ & $\checkmark$ & $\checkmark$ \\
\hline Health at $\mathrm{t}_{-1}$ & $\begin{array}{c}0.143 * * * \\
(0.0137)\end{array}$ & $\begin{array}{c}0.142 * * * \\
(0.0138)\end{array}$ & $\begin{array}{c}0.141 * * * \\
(0.0137)\end{array}$ & $\begin{array}{c}0.141 * * * \\
(0.0142)\end{array}$ & $\begin{array}{c}0.144 * * * \\
(0.0137)\end{array}$ & $\begin{array}{c}0.143 * * * \\
(0.0138)\end{array}$ & $\begin{array}{c}0.139 * * * \\
(0.0139)\end{array}$ \\
\hline Health at $\mathrm{t}_{-2}$ & $\begin{array}{c}0.0671 * * * \\
(0.0122)\end{array}$ & $\begin{array}{c}0.0657 * * * \\
(0.0124)\end{array}$ & $\begin{array}{c}0.0640 * * * \\
(0.0122)\end{array}$ & $\begin{array}{c}0.0671 * * * \\
(0.0123)\end{array}$ & $\begin{array}{c}0.0678 * * * \\
(0.0122)\end{array}$ & $\begin{array}{c}0.0674 * * * \\
(0.0123)\end{array}$ & $\begin{array}{c}0.0643 * * * \\
(0.0123)\end{array}$ \\
\hline Unemployed at $t_{0}$ & $\begin{array}{c}-0.180 * * * \\
(0.0488)\end{array}$ & & $\begin{array}{c}-0.199 * * * \\
(0.0509)\end{array}$ & $\begin{array}{l}-0.109 \# \\
(0.0634)\end{array}$ & $\begin{array}{c}-0.186^{* * * *} \\
(0.0491)\end{array}$ & $\begin{array}{c}-0.194 * * * \\
(0.0497)\end{array}$ & $\begin{array}{l}-0.142^{*} \\
(0.0619)\end{array}$ \\
\hline $\begin{array}{l}\text { Unemployment } \\
\text { duration (month) } \\
\text { at } t_{0}\end{array}$ & & $\begin{array}{c}- \\
0.00275^{* * *} \\
(0.000514)\end{array}$ & & & & & \\
\hline $\begin{array}{l}\text { Household income } \\
\text { (in } 100 € \text { ) at } t_{0}\end{array}$ & & & $\begin{array}{l}-0.00249 \\
(0.00258)\end{array}$ & & & & $\begin{array}{l}-0.00254 \\
(0.00274)\end{array}$ \\
\hline $\begin{array}{l}\text { Self-perceived } \\
\text { Social Status at } t_{0} \\
(\text { low }=10)\end{array}$ & & & & $-0.0671 \#$ & & & $-0.0730 *$ \\
\hline Strong Ties at $t_{0}$ & & & & $(0.0377)$ & $\begin{array}{l}-0.00527 \\
(0.00818)\end{array}$ & & $\begin{array}{l}(0.0342) \\
-0.00112 \\
(0.00752)\end{array}$ \\
\hline Weak Ties at $t_{0}$ & & & & & & $\begin{array}{l}-0.211^{*} \\
(0.0912)\end{array}$ & $\begin{array}{l}-0.229 * \\
(0.0904)\end{array}$ \\
\hline Constant & $\begin{array}{c}2.549 * * * * \\
(0.156)\end{array}$ & $\begin{array}{c}2.500 * * * \\
(0.113)\end{array}$ & $\begin{array}{c}2.565 * * * \\
(0.158)\end{array}$ & $\begin{array}{c}2.907 * * * \\
(0.276)\end{array}$ & $\begin{array}{c}2.563 * * * * \\
(0.156)\end{array}$ & $\begin{array}{c}2.555^{* * * *} \\
(0.158)\end{array}$ & $\begin{array}{c}2.964 * * * \\
(0.264)\end{array}$ \\
\hline Observations & 31,939 & 31,618 & 31,690 & 31,761 & 31,876 & 31,926 & 31,451 \\
\hline Number of persons & 11,506 & 11,397 & 11,443 & 11,464 & 11,486 & 11,503 & 11,382 \\
\hline
\end{tabular}

Robust standard errors in parentheses; $* * * \mathrm{p}<0.001,{ }^{*} * \mathrm{p}<0.01, * \mathrm{p}<0.05, \# \mathrm{p}<0.10$ 
Table A 5: Results for psychological health (equivalent to Table 2)

\begin{tabular}{|c|c|c|c|c|c|c|c|}
\hline & Model (1) & Model (2) & Model (3) & Model (4) & Model (5) & Model (6) & Model (7) \\
\hline & sysGMM & sysGMM & sysGMM & sysGMM & sysGMM & sysGMM & sysGMM \\
\hline & $\begin{array}{c}\text { Coeff } \\
\text { (std.err) }\end{array}$ & $\begin{array}{c}\text { Coeff } \\
\text { (std.err) }\end{array}$ & $\begin{array}{c}\text { Coeff } \\
\text { (std.err) }\end{array}$ & $\begin{array}{c}\text { Coeff } \\
\text { (std.err) }\end{array}$ & $\begin{array}{c}\text { Coeff } \\
\text { (std.err) }\end{array}$ & $\begin{array}{c}\text { Coeff } \\
\text { (std.err) }\end{array}$ & $\begin{array}{c}\text { Coeff } \\
\text { (std.err) }\end{array}$ \\
\hline Covariates & $\checkmark$ & $\checkmark$ & $\checkmark$ & $\checkmark$ & $\checkmark$ & $\checkmark$ & $\checkmark$ \\
\hline Health at $t_{-1}$ & $\begin{array}{c}0.141 * * * \\
(0.0133)\end{array}$ & $\begin{array}{c}0.138 * * * \\
(0.0138)\end{array}$ & $\begin{array}{c}0.142 * * * \\
(0.0132)\end{array}$ & $\begin{array}{c}0.138 * * * \\
(0.0135)\end{array}$ & $\begin{array}{c}0.143 * * * \\
(0.0135)\end{array}$ & $\begin{array}{c}0.142 * * * \\
(0.0133)\end{array}$ & $\begin{array}{c}0.140 * * * \\
(0.0135)\end{array}$ \\
\hline Health at $t_{-2}$ & $\begin{array}{c}0.0700 * * * \\
(0.0117)\end{array}$ & $\begin{array}{c}0.0680 * * * \\
(0.0120)\end{array}$ & $\begin{array}{c}0.0695 * * * \\
(0.0116)\end{array}$ & $\begin{array}{c}0.0730 * * * \\
(0.0117)\end{array}$ & $\begin{array}{c}0.0702 * * * \\
(0.0117)\end{array}$ & $\begin{array}{c}0.0706 * * * \\
(0.0117)\end{array}$ & $\begin{array}{c}0.0740 * * * \\
(0.0116)\end{array}$ \\
\hline Unemployed at $t_{0}$ & $\begin{array}{l}-0.126^{*} \\
(0.0600)\end{array}$ & & $\begin{array}{l}-0.104 \# \\
(0.0622)\end{array}$ & $\begin{array}{c}0.0437 \\
(0.0766)\end{array}$ & $\begin{array}{l}-0.138^{*} \\
(0.0608)\end{array}$ & $\begin{array}{l}-0.129 * \\
(0.0610)\end{array}$ & $\begin{array}{c}0.0157 \\
(0.0755)\end{array}$ \\
\hline $\begin{array}{l}\text { Unemployment } \\
\text { duration (month) } \\
\text { at } t_{0}\end{array}$ & & $\begin{array}{l}{ }^{-} \\
0.00212 * * * \\
(0.000550)\end{array}$ & & & & & \\
\hline $\begin{array}{l}\text { Household income } \\
\text { (in } 100 € \text { ) at } t_{0}\end{array}$ & & & $\begin{array}{l}0.00289 \\
(0.00314)\end{array}$ & & & & $\begin{array}{l}-4.13 e-05 \\
(0.00285)\end{array}$ \\
\hline $\begin{array}{l}\text { Self-perceived } \\
\text { Social Status at } t_{0} \\
(\text { low }=10)\end{array}$ & & & & $-0.159 * * *$ & & & $-0.143 * * *$ \\
\hline Strong Ties at $t_{0}$ & & & & $(0.0428)$ & $\begin{array}{c}-0.00698 \\
(0.00869)\end{array}$ & & $\begin{array}{l}(0.0390) \\
-0.00455 \\
(0.00870)\end{array}$ \\
\hline Weak Ties at $t_{0}$ & & & & & & $\begin{array}{l}-0.0817 \\
(0.111)\end{array}$ & $\begin{array}{c}-0.148 \\
(0.107)\end{array}$ \\
\hline Constant & $\begin{array}{c}3.263 * * * \\
(0.190)\end{array}$ & $\begin{array}{c}3.163 * * * \\
(0.138)\end{array}$ & $\begin{array}{c}3.193 * * * \\
(0.191)\end{array}$ & $\begin{array}{c}4.148 * * * \\
(0.317)\end{array}$ & $\begin{array}{c}3.284 * * * \\
(0.194)\end{array}$ & $\begin{array}{c}3.207 * * * \\
(0.191)\end{array}$ & $\begin{array}{l}3.960 * * * \\
(0.308)\end{array}$ \\
\hline Observations & 31,874 & 31,553 & 31,628 & 31,702 & 31,814 & 31,863 & 31,397 \\
\hline Number of persons & 11,480 & 11,371 & 11,417 & 11,441 & 11,461 & 11,477 & 11,360 \\
\hline
\end{tabular}

Robust standard errors in parentheses; $* * * p<0.001, * * \mathrm{p}<0.01,{ }^{*} \mathrm{p}<0.05, \# \mathrm{p}<0.10$ 
Table A 6: Mechanism Tests, equivalent to Table 2, but fixed-effects regressions

\begin{tabular}{|c|c|c|c|c|c|c|}
\hline & Model (1) & Model (2) & Model (3) & Model (4) & Model (5) & Model (6) \\
\hline & $\begin{array}{l}\text { Fixed- } \\
\text { Effects }\end{array}$ & $\begin{array}{l}\text { Fixed- } \\
\text { Effects }\end{array}$ & $\begin{array}{l}\text { Fixed- } \\
\text { Effects }\end{array}$ & $\begin{array}{l}\text { Fixed- } \\
\text { Effects }\end{array}$ & $\begin{array}{l}\text { Fixed- } \\
\text { Effects }\end{array}$ & $\begin{array}{l}\text { Fixed- } \\
\text { Effects }\end{array}$ \\
\hline & $\begin{array}{c}\text { Coeff } \\
\text { (std.err) }\end{array}$ & $\begin{array}{c}\text { Coeff } \\
\text { (std.err) }\end{array}$ & $\begin{array}{c}\text { Coeff } \\
\text { (std.err) }\end{array}$ & $\begin{array}{c}\text { Coeff } \\
\text { (std.err) }\end{array}$ & $\begin{array}{c}\text { Coeff } \\
\text { (std.err) }\end{array}$ & $\begin{array}{c}\text { Coeff } \\
\text { (std.err) }\end{array}$ \\
\hline Covariates & $\checkmark$ & $\checkmark$ & $\checkmark$ & $\checkmark$ & $\checkmark$ & $\checkmark$ \\
\hline Unemployed at $\mathrm{t}_{0}$ & $\begin{array}{c}-0.248 * * * \\
(0.0314)\end{array}$ & $\begin{array}{c}-0.244 * * * \\
(0.0316)\end{array}$ & $\begin{array}{c}-0.220 * * * \\
(0.0315)\end{array}$ & $\begin{array}{c}-0.240 * * * \\
(0.0315)\end{array}$ & $\begin{array}{c}-0.247 * * * \\
(0.0314)\end{array}$ & $\begin{array}{c}-0.209 * * * \\
(0.0318)\end{array}$ \\
\hline $\begin{array}{l}\text { Household income } \\
\text { (in } 100 € \text { ) at } t_{0}\end{array}$ & & $\begin{array}{l}0.000364 \\
(0.000296)\end{array}$ & & & & $\begin{array}{l}0.000239 \\
(0.000297)\end{array}$ \\
\hline $\begin{array}{l}\text { Self-perceived } \\
\text { Social Status at } t_{0} \\
(\text { low }=10)\end{array}$ & & & $\begin{array}{c}- \\
0.0694 * * * \\
(0.00589)\end{array}$ & & & $\overline{-}^{-}$ \\
\hline Strong Ties at $t_{0}$ & & & & $\begin{array}{c}0.00394 * * \\
(0.00135)\end{array}$ & & $\begin{array}{c}0.00384 * * \\
(0.00138)\end{array}$ \\
\hline Weak Ties at $t_{0}$ & & & & & $\begin{array}{c}0.0359 \\
(0.0229)\end{array}$ & $\begin{array}{c}0.0323 \\
(0.0233)\end{array}$ \\
\hline Constant & $\begin{array}{c}6.843 * * * \\
(0.345)\end{array}$ & $\begin{array}{c}6.796 * * * \\
(0.349)\end{array}$ & $\begin{array}{c}7.278 * * * \\
(0.347)\end{array}$ & $\begin{array}{c}6.954 * * * \\
(0.332)\end{array}$ & $\begin{array}{c}6.839 * * * \\
(0.345)\end{array}$ & $\begin{array}{c}7.328 * * * \\
(0.337)\end{array}$ \\
\hline Observations & 69,734 & 68,991 & 69,218 & 69,428 & 69,703 & 68,200 \\
\hline Number of persons & 21,063 & 20,975 & 20,974 & 21,026 & 21,059 & 20,848 \\
\hline
\end{tabular}


Table A 7: Sensitivity Analysis Table 2, Model 1

\begin{tabular}{|c|c|c|c|}
\hline & Orig. Model (Tabel 2) & $\begin{array}{c}3 \text { lag IV } \\
\text { Model }\end{array}$ & $\begin{array}{c}\text { Age restricted } \\
\text { Model }\end{array}$ \\
\hline & sysGMM & sysGMM & sysGMM \\
\hline & $\begin{array}{l}\text { Coeff } \\
\text { (std.err) }\end{array}$ & $\begin{array}{l}\text { Coeff } \\
\text { (std.err) }\end{array}$ & $\begin{array}{l}\text { Coeff } \\
\text { (std.err) }\end{array}$ \\
\hline Covariates & $\checkmark$ & $\checkmark$ & $\checkmark$ \\
\hline Unemployed at $\mathrm{t}_{0}$ & $\begin{array}{c}-0.573 * * * \\
(0.104)\end{array}$ & $\begin{array}{c}-0.345^{* *} \\
(0.125)\end{array}$ & $\begin{array}{l}-0.321^{*} \\
(0.142)\end{array}$ \\
\hline Health at $\mathrm{t}_{-1}$ & $\begin{array}{c}0.195^{* * *} \\
(0.0165)\end{array}$ & $\begin{array}{c}0.186^{* * *} \\
(0.0168)\end{array}$ & $\begin{array}{c}0.178 * * * \\
(0.0188)\end{array}$ \\
\hline Health at $\mathrm{t}_{-2}$ & $\begin{array}{c}0.0779 * * * \\
(0.0131) \\
\end{array}$ & $\begin{array}{c}0.0709 * * * \\
(0.0133) \\
\end{array}$ & $\begin{array}{c}0.0725 * * * \\
(0.0148) \\
\end{array}$ \\
\hline Constant & $\begin{array}{c}4.598^{* * *} \\
(0.306) \\
\end{array}$ & $\begin{array}{c}6.039 * * * \\
(0.514) \\
\end{array}$ & $\begin{array}{c}6.713 * * * \\
(0.610) \\
\end{array}$ \\
\hline $\begin{array}{l}\text { Observations } \\
\text { Number of Persons }\end{array}$ & $\begin{array}{l}31,969 \\
11,512\end{array}$ & $\begin{array}{l}31,480 \\
11,388\end{array}$ & $\begin{array}{c}25,508 \\
9,600\end{array}$ \\
\hline Tests & & & \\
\hline $\begin{array}{l}\text { Arellano-Bond Test AR } 2 \text { (p-value) } \\
\text { Hansen J-Test (p-value) }\end{array}$ & $\begin{array}{l}0.915 \\
0.460\end{array}$ & $\begin{array}{l}0.612 \\
0.119\end{array}$ & $\begin{array}{l}0.678 \\
0.701\end{array}$ \\
\hline
\end{tabular}

